\title{
Big Plans, Small Steps: Learnings from Three Decades of Mobilising Resources for Women's Rights
}

\section{Zohra Moosa and Happy Mwende Kinyili*}

\begin{abstract}
The women's funding movement has contributed to and been a product of women's rights movements around the world. This article looks at the history of Mama Cash, the first international women's fund, to chart how the effort to mobilise resources for women's rights activism has been going - before and since the Fourth World Conference on Women held in Beijing in 1995.
\end{abstract}

Mama Cash is the oldest international women's fund in the world. Founded in 1983, it exists to mobilise resources from individuals and institutions, including both private and public foundations as well as governments, and redistribute them to groups and movements led by women, girls and trans* people to advance their human rights. It channels the resources it raises directly to groups and movements through a grants system.

\section{Introduction}

The Forum of the Fourth World Conference on Women in Beijing in 1995 was a seminal moment for women's rights. It built on political agreements made by governments in the previous three world conferences on women to develop the landmark Beijing Declaration and Platform for Action (BPfA). The BPfA formally recognised women's rights as human rights and offered a coherent strategy for governmental organisations and non-governmental organisations (NGOs) to concretely and fairly comprehensively advance these rights. It remains a cornerstone document for the vision and elaboration of women's rights to this day.

The conference also demonstrated the importance and impact of collective action in creating social and political change. The women's rights advocates in Beijing worked tirelessly, and ultimately successfully, to influence governments, and the creation and content of the BPfA. Key to this effort was the financing that facilitated the collective action of the women's rights activists in attendance.
The importance of women's funds - in particular in resourcing collective action and women's rights movements more generally - had been identified prior to 1995, and there were a few women's funds already working around the world by the time of the Beijing conference. These funds understood how financing for women's rights activism, collective action and feminist movements was one of the most important drivers for sustainable social change on women's rights. Recognising the opportunity that the Beijing conference offered for women's rights, these women's funds were deliberate in their strategy of attending themselves and of supporting activists to participate and mobilise together in Beijing to help secure the BPfA. The BPfA, in turn, influenced back the strategies and efforts of these women's funds after the conference, as well as seeding the need for even more women's funds to develop. At the time of its creation in 1983, Mama Cash was unique. It was for the first time providing funding both nationally and internationally to initiatives led by women and about women's rights. The Global Fund for Women was created a few years later and was based on the Mama Cash model - global and not focused on any particular sub-set of women. It was only after the BPfA was developed that the women's fund model began truly flourishing; by the late 1990s and early 2000s, autonomous national and regional women's funds were being created and growing across Africa, Asia and Latin America.

There are now almost 40 national, regional and international women's funds around the world, and 
many more working inside the US alone. Those outside the US mostly focus their grant-making based on geography, but there are a few that are population and issue-based that work globally, such as FIMI, the Indigenous Women's Fund; FRIDA, the young feminist fund; and the three Urgent Action Funds, which conduct rapid response grant-making in times of great opportunity or risk for feminist activists.

The many advances that have been made by feminist movements in the last two decades include how we have resourced our movements and ourselves to do this work. The resilience of today's women's funding movement is itself a testament to, as well as a source of support for, the strength of feminist movements around the world. This resilience has not been easily formed, and it is still, even today, constantly tested. In reviewing Mama Cash's own efforts to continue to support and sustain feminism/ists over the last 30 years, we can learn a little bit about the role that resources and processes of resourcing play in organising by women, girls and trans* people. And we can also learn what types of resourcing support women, girls and trans* people to build movements that are responsive, effective and resilient - and ultimately successful at securing the various changes we seek in the world. ${ }^{2}$

\section{Mama Cash's initial strategies}

In 1973, the Amsterdam-based feminist Marjan Sax received a considerable inheritance. For a while, she was not quite sure what to do with it. At that time, the women's movement in the Netherlands had close connections with the left-wing movement, and both were anti-capitalist. Having significant money at one's disposal was seen as suspicious. As Sax admits, 'When entering a bank, first thing I'd do was check whether anybody had seen me'.

Mama Cash began when Sax sat down with four other lesbians from the Dutch women's movement at a kitchen table in Amsterdam to talk about what she should do with her inherited wealth. By 1982, they had the plan to start an initiative that would develop into an international grant-making organisation that supports women, girls and trans* people around the globe in their fight for equal rights.

Mama Cash's five founders decided to focus on women's activism. Sax gave Mama Cash a loan of 2.5 million guilders $(€ 1,135,000)$, and the interest funded the organisation. They were determined to bring about worldwide change from a feminist perspective. At the onset, Mama Cash described itself as an organisation that would promote worldwide 'women's empowerment and feminism'. The first annual report stated: 'To Mama Cash, feminism is a radical strategy for change. Therefore, it follows that she focuses more on change than on maintaining the status quo'. This also meant challenging the white, Western, heterosexual norm. Organisations qualifying for a grant, loan or guarantee would have to be run by a woman or a collective of women.

Mama Cash supported Dutch women's initiatives and those of women in the global South. The autonomy of women and the right to make their own decisions about their bodies and lives was a central issue within the women's movements of the 1970s and 1980s. This was also true for Mama Cash. During those first years, its lesbian founders focused mostly on the right of women to own their own bodies and sexuality. They operated on the beliefs that lesbian women should be visible, and the heterosexual norm should be challenged; sex workers should have the same rights as any other women; women should have access to safe abortion; in cases of violence, women should have access to a safe place to stay and violence prevention measures should be taken; and women fighting against female genital cutting should also be able to count on Mama Cash for support. Mama Cash was not willing to provide money for traditional development aid: 'No weaving baskets' and 'No digging water wells', founders Marjan Sax and Lida van den Broek declared respectively, and independently of each other.

In addition, there was also a strong emphasis on funding 'the autonomous women's press' counterculture projects where women were able to have and present alternative voices and opinions to the mainstream press in the Netherlands. This included support to radio programmes, publishers, archives, centres for documentation, printers and bookstores for and by women. And in the Netherlands, projects run by and for Black women were prioritised.

Near the end of the 1980s, the five founders had to make an important decision about the future. Should they continue relying on volunteers and holding their board meetings in a kitchen with a filing cabinet? Or should they take a step towards professionalisation? The latter would imply Mama Cash becoming a formal organisation with the expectation of growth, a future, employees and a hierarchy. Despite a temporary, yet alarming, financial setback caused by the 1987 stock market crash, and despite the tax department unexpectedly charging capital transfer tax on Mama Cash's start-up capital, Mama Cash 
was already outgrowing its kitchen table. But it still fancied itself as an outsider that happened to have money at its disposal. Mama Cash had to re-evaluate its self-image.

The women of Mama Cash also started to realise that, if they wanted to change the world, they had better think big(ger). When Mama Cash was founded, it had the interest from Marjan Sax's 2.5 million guilders loan at its disposal for a period of ten years. Since there was no cause for financial concern during those first years, Mama Cash had been able to focus on developing relevant policies and working strategies. But before long, raising additional funds would be necessary: after ten years Mama Cash would have to start paying back the 1983 interest-free loan to its founder. It would need financial autonomy to survive. For all of these reasons, in 1989 Mama Cash decided to start mobilising resources of its own through fundraising.

\section{The Fourth World Conference on Women}

The early 1990s marked a period of further change and growth for Mama Cash. The number of paid staff doubled, mobilising resources became a core objective for the organisation, and in 1995, Mama Cash hired its first paid professionally qualified fundraiser.

That same year, over 25,000 women from all over the world gathered for the Fourth World Conference on Women in Beijing. At the conference, several American women's funds organised a meeting about the need for independent resources to flow through independent women's funds to women's rights organisations. Semillas, a women's fund in Mexico, had launched in 1991. Many women in other parts of the world had also started to think about setting up local and regional women's funds. Mama Cash supported these initiatives with start-up grants, as well as with solidarity and networking support.

Mama Cash organised a well-attended workshop at the Beijing conference about its activities and role as a funder. Women from Africa challenged those present at the conference, arguing that a western capitalist model of development was being imposed on them. Activists declared that funding models that the global North used to 'assist' the global South amounted to a new form of colonialism. As a result of these discussions, Mama Cash questioned its own role in replicating these top-down funding models and decided to change its grants decision-making structure.
After the conference, Mama Cash increased the international network of advisers it used in the course of making its grants. Advisers were selected for their local, national and regional expertise of the women's rights movement and they could provide information about groups requesting support, the local circumstances the group was operating in, and the role and influence of the group in that area. During the mid-1990s, the network consisted of about 80 advisers. Ten years later, the number had grown to almost 200.

\section{Identity crisis and rejuvenation}

Partly as a result of the success of the Beijing conference and other efforts by feminists, the attention to women's rights greatly increased by the mid to late 1990s. For Mama Cash, this also translated into growing support, including financial support, from more mainstream development organisations. In addition, these other organisations were also creating their own women's programmes. For Mama Cash, these successes led to deep questions about its niche and purpose: if everyone was now interested in what Mama Cash had been advocating, what should Mama Cash now be pushing for, if it was still to be the radical feminist organisation it wanted to be?

\section{In 1997, Mama Cash appointed Lilianne Ploumen} as its first ever executive director. When its first paid staff person had been hired ten years earlier, Mama Cash had done so with the resolve never to become a mainstream, bureaucratic foundation. With this still in mind, personnel policies and public articulation of the core themes it intended to organise its work around were developed. Debates ensued about sources of funding and ultimately the decision was made to accept donations from more mainstream donors, including the Dutch government and some US foundations. In Ploumen's words, Mama Cash moved from a principle of not taking 'mainstream money', to 'Our most important principle became maintaining our independence to decide on what we wanted to spend the money'. ${ }^{3}$

Near the end of the 1990s, the character of the financial support offered by Mama Cash also changed. There was a recognition that shortterm commitments and small grants were not contributing to the sustainability of women's groups in the long term. Groups were returning to Mama Cash after each funding round, and each time with relative uncertainty about whether they would be funded again. 
At the same time, the number of requests to Mama Cash was steadily increasing - demonstrating that women were organising for their rights and were looking for financial support for their efforts. Mama Cash had been taking a 'let many flowers bloom' approach, trying to spread its resources as widely as possible. During the period 1991-5 Mama Cash granted $€ 846,000$ to 711 groups. From 1996-2000, Mama Cash granted $€ 4,185,000$ to 2,225 groups there was a clear growth path. As the demand for funding grew, the organisation found that it needed to develop more internal guidance about which groups to support and which to decline. The criteria were re-examined once more in 2001 and a decision to support the women and girls who were most often excluded, including those marginalised within feminist movements, was taken. This included lesbian women, sex workers, women living in the countryside and indigenous women. From 2001-03, Mama Cash granted $€ 3,867,000$ to 1,197 groups.

\section{Movement building: the new approach}

In 2000 Mama Cash and other women's funds came together to create the International Network of Women's Funds (INWF) to jointly strategise, learn and develop tools and capacities to strengthen the work of women's funds and their grantees. The INWF grew from a network of nine funds to its current membership of 42 women's funds working around the world. The network has maintained a clear political voice in the donor community as a funders' space that builds and uses financial and other resources for feminist social change.

As part of a broader network of women's funds, Mama Cash continued to work to clearly define its niche and focus in order to try to channel its limited resources to as powerful an effect as it could conceive. These decisions crystallised into a much clearer movement-building approach. Mama Cash developed its first strategic plan in 2004, which had a strong emphasis on being more deliberate about linking grant-making to a vision and objectives that were defined, understood and tracked. During the period 2004-08 Mama Cash granted €12,159,000 to 1,234 groups, continuing the slow trend of granting larger sums of money to a relatively fewer number of groups.

Mama Cash actively sought to strengthen the women's funding movement during this period as part of its contribution to movement building, and did so in collaboration with other women's funds and with the INWF and the Women's Funding Network (WFN). Feminist organisations had grown in size significantly in the new millennium, and their influence had increased substantially. Together with other women's funds, Mama Cash tested 'Making the Case', a new tool developed by the WFN that helped evaluate both the impact of grants awarded and the grantees. Working directly with WFN, Mama Cash also supported the creation of a tool for the organisational development of women's funds called 'Smart Growth', which looked at how best to strengthen and sustain women's funds.

In 2007, Mama Cash started to advance a plan to get governments, foundations and NGOs to invest more money in women's rights. That year, the Dutch government created the 'MDG 3 Fund' in accordance with UN Millennium Development Goal 3: equal rights for women and girls by 2015. Mama Cash worked together with several organisations, including Hivos, Cordaid and Oxfam Novib, and assisted the government to develop criteria and guidelines for the new fund. Mama Cash was not itself eligible to apply to the MDG 3 Fund, but it was committed to enabling marginalised groups within the women's movement to receive money from this substantial initiative. Mama Cash succeeded in having the subsidy threshold lowered to $€ 300,000$ from the initial $€ 700,000$, thereby ensuring that smaller organisations would be able to request financial support. The MDG 3 Fund was a great success. Because of the quality of the requests, the Dutch government granted $€ 70$ million to 45 women's rights organisations and funds in 2008 (14 of which were former Mama Cash grantees), an increase over the initially projected $€ 50$ million.

By its second strategic plan, in 2009, Mama Cash was articulating a theory of change on resourcing women's rights movements. There was a shift to providing longer-term support to groups, including multi-year grants, to increase groups' abilities to plan and strategise and also contribute to their sustainability and resilience. A stock-take with groups as part of the research to develop the 2009 plan had found that groups were spinning their wheels and in constant fundraising mode - larger, multi-year grants aimed to shift this. The second strategic plan also made an intentional move to support groups that were 'self-led', prioritising groups led by women and girls that tended to be more excluded, but who were organising and speaking out for themselves. The process of organising was treated as just as important as the planned outcome. During the 2009-15 period Mama Cash also became more explicit about supporting trans* people and trans* rights organising - irrespective of their gender identity. 
It was recognised that trans* people often face discrimination for the same reasons that women and girls historically are discriminated against - because of their (perceived) gender identity.

Another change Mama Cash made was from providing project funding to providing core funding - where groups were granted support on the basis of their visions, missions and ways of organising rather than specific project outcomes, with full flexibility to spend the funding on what they thought the priorities for their groups were, based on their understanding of their realities and contexts, and including general operating costs such as rent or salaries or office equipment. This core support was complemented by 'accompaniment' support: time and resources from Mama Cash to enable groups to strengthen in the ways they thought important to achieving their longer-term goals. Feedback from groups that Mama Cash had supported repeatedly emphasised that financial support was not sufficient for them to build and sustain their movements; they wanted other kinds of support from the organisation, especially where Mama Cash could do something unique for them such as provide an introduction to similar groups, or other potential donors. Mama Cash's accompaniment support thus began to include more traditional training on skills such as strategic planning, fundraising, managing leadership transitions, and conducting an audit, as well as tailored opportunities such as linking them to other grantees so that they could identify common challenges, trade promising strategies for change, and form or deepen alliances.

Since 2010, these changes have become even more formalised. As a result, core, flexible, longer-term and multi-year funding, with accompaniment support, is the basis of Mama Cash's new strategic plan, launched in 2015. A focus on self-led groups is also a given for Mama Cash, recognised as a key organising principle of feminist organising.

\section{Resourcing women's rights activism through the women's funding movement}

While the number of international development funding agencies that prioritise women's, girls' and trans* people's issues has grown, women's funds continue to occupy a distinct position in global and local funding landscapes (Esplen 2013). They raise and distribute critical resources for women's, girls', and trans* people's activism. Research published in 2006 by the Association for Women's Rights in Development (AWID 2006) showed that women's funds were the main source of income for women's rights groups with annual budgets under US $\$ 50,000$, while its more recent research confirms that almost ten years later, women's funds remain a critical source of funding for small women's rights organisations (Arutyunova and Clark 2013).

The impact that women's funds have had since Beijing and that Beijing had on women's funds should not be underestimated. As Mama Cash's own work also shows, strong women's funds are key to building powerful, effective women's and feminist movements (Moosa and Daly 2015). In countries where they are active, they are often the first and main source of support for new or non-mainstream groups, including groups that are not legally registered. They are able to act fast, supporting demonstrations or providing urgent assistance to activists who are at risk. They tend to innovate and are able to take more useful risks because of their deep expertise and also their connections to the groups they are funding. Their infrastructures are designed to serve their target groups, the feminist groups that lead feminist movements. Their work is fundamental in contexts where there is little history of local philanthropy, especially philanthropy to support rights-based work. And they increase awareness among local and international institutional and individual donors, corporations and governments about the critical importance of supporting and funding women's rights activism - an area of growing understanding for many (Cornwall and Edwards 2015). Indeed, one legacy of Beijing is the recognition of how the collective action of women, girls and trans* people can and does produce social change.

Besides supporting grassroots groups, women's funds also have an important role to play in mobilising resources for feminist movements including by building local feminist philanthropy around the world. In most countries, public giving is framed as charity rather than a commitment to social justice and transformation. Human rights activism which pushes the boundaries of people's understanding of 'charity' can be more difficult to fundraise for locally. This is especially true in countries which are experiencing a rise of religious, cultural or political fundamentalisms. Many states restrict civil society organising, particularly if groups are using a human rights approach to their work. This can make it difficult to build a culture of local feminist philanthropy, as people are reluctant to fund this work when the environment is hostile to human rights activism that challenges the status quo. Women's funds take on this challenge, 
creating understandings among individuals and governmental and other institutions about why financing for women's rights activism is necessary.

As more women's funds are created and consolidated, the opportunities for shared learning and strategising are also growing. 'The Community of Practice of Young Women and Girls' (Mama Cash 2012) that Mama Cash helped to coordinate with the Central American Women's Fund (FCAM) was a multi-year programme that brought together women's funds from around the world to support girls' and young women's activism. Initiated with funding from the Nike Foundation's Grassroots Girls Initiative, the Community of Practice provided an opportunity for women's funds to learn from one another, to make their own practices more responsive to the needs of girls' organisations, and to change the funding landscape so that it was more accessible to girl-led human rights organisations across the world. When the collaboration first began in 2011, only two out of the 11 member funds had programmes specifically dedicated to funding young women and girls. By 2013, all members had either established such programmes or were funding significant numbers of groups of young women and girls as part of their standard programmes.

\section{Conclusion: financing feminist futures}

Most women's funds around the world are fairly young - less than ten years old. They are still defining their identity, their role in the feminist and women's rights movements, as well as determining their relationship to other social movements. At the

\section{Notes}

* This article is written by the authors on behalf of Mama Cash.

1 To respect their preference, Mama Cash uses the name 'trans*' with an asterisk, denoting a placeholder for the 'entire range of possible gender identities that fall under the broad definition of trans' (see Global Action for Trans* Equality and American Jewish World Service 2014: 3). Mama Cash explicitly supports trans* activism that is guided by feminist perspectives same time, women's funds are becoming increasingly clear and focused about their unique role in funding the collective action of women, girls and trans* people and in building local feminist philanthropy, trying out and refining their strategies to do so, and in many contexts slow but steady progress in both areas can already be seen. As with all emerging actors within the feminist movement, many doors are open and it is impossible - but also very exciting - to predict where women's funds will be in another 30 years from now.

As the oldest and one of the largest women's funds worldwide, Mama Cash supports other women's funds working nationally or regionally in the global South and East, including emerging funds. It supports women's funds because it recognises the need to expand and diversify feminist funding sources for women's, girls', and trans* people's activism globally. The work of these funds and the movements they support is critical to achieving sustainable social change and advancing women's rights. Autonomous women's movements have been shown to be the most critical factor in such change (Htun and Weldon 2012). And there is mounting evidence about the importance of financing these movements, in turn (Alpízar Durán 2015).

One of the most important legacies of the Beijing conference has been exactly this: recognition of the importance of the collective action of women, girls and trans* people, as well as the women's funds that sustain it.

because of its commitment to support work that transforms unequal gender power relations, and an acknowledgement that women's rights movements are questioning the limits of a binary definition of gender and exploring ways to include trans* perspectives.

2 The source for most of this content is Mama Cash's history website at: www.history.mamacash.nl.

3 See http://history.mamacash.nl/history-page/ money-from-institutional-donors. 


\section{References}

[All urls checked 28 May 2015]

Alpízar Durán, L. (2015) 20 Years of Shamefully Scarce Funding for Feminists and Women's Rights Movements, UNRISD, www.unrisd.org/UNRISD/ website/newsview.nsf/\%28httpNews\%29/ ACCD0FD07EFC887AC125744002B9333? OpenDocument

Arutyunova, A. and Clark, C. (2013) Watering the Leaves, Starving the Roots: The Status of Financing for Women's Rights Organizing and Gender Equality, AWID, www.awid.org/sites/default/files/atoms/files/ WTL_Starving_Roots.pdf

AWID (Association for Women's Rights in Development) (2006) Where is the Money for Women's Rights... and How Can We Tap It? , Factsheet 4, www.awid.org/sites/default/files/atoms/files/ witm_-_factsheet_4.pdf

Cornwall, A. and Edwards, J. (2015) How Feminist Activism can make States more Accountable for Women's Rights, UNRISD, www.unrisd.org/beijing+20cornwall-edwards
Esplen, E. (2013) 'Leaders for Change: Why Support Women's Rights Organisations?', Womankind Worldwide, March, www.womankind.org.uk/ wp-content/uploads/downloads/2013/03/ LeadersForChange-FINAL.pdf

Global Action for Trans* Equality and American Jewish World Service (2014) The State of Intersex and Trans* Organising, http://globaltransaction.files. wordpress.com/2014/01/trans-intersex-fundingreport.pdf

Htun, M. and Weldon, S.L. (2012) 'The Givic Origins of Progressive Policy Change: Combating Violence against Women in Global Perspective, 1975-2005', American Political Science Review 106.3: 548-69

Mama Cash (2012) 'Community of Practice' Supports Girls' Activism, 8 March, www.mamacash.org/news/ community-of-practice-supports-girls-activism

Moosa, Z. and Daly, S. (2015) Investing Well in the Right Places: Why Fund Women's Funds, Mama Cash, February, www.mamacash.org/content/ uploads/2015/02/Mama-Cash-Why-WomensFunds_Feb-2015_FINAL.pdf 